\title{
Anmeldelse: Ukraines historie
}

Af Mette Skak

Der findes både gode og dårlige bøger om Ukraine. På dansk foreligger Andrej Kurkovs fine øjenvidneberetning fra Majdan-revolutionen Den ukrainske dagbog. (Kijev 21. 11. 2013 - 24. 4. 2014), hvorimod Richard Sakwa har begået en mere problematisk bog - Frontline Ukraine - som det fremgår af de danske og svenske anmeldelser.

Andreas Kappeler: Ukraines historie. Oversat fra tysk af Jens Ellekær. Ellekณrs forlag, 2016. $481 \mathrm{~s}$.

Den bog, der her skal anmeldes, er sober, velskrevet og appetitlig, idet den rummer et billedgalleri bagest. Den giver en fornem indføring i Ukraines historie og kan varmt anbefales. Selv om det ikke kommer bogen ved, er forlæggeren og oversætteren identisk med den ene af to danske agenter, der i 1980'erne i den kolde krigs Polen blev arresteret for spionage - en prekær sag for Danmark og voldsomt ubehagelig for de to pågrebne. Her demonstrerer Ellekær sine sprogkund-

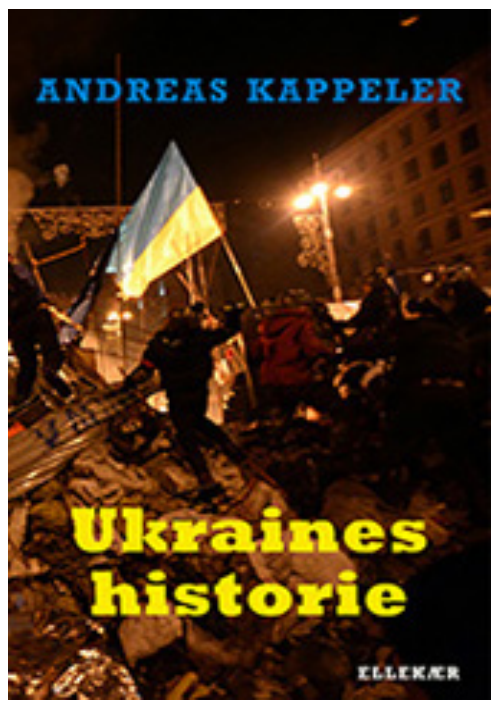

skaber, dog med lidt svipsere ved korrekturlæsningen og et helt afsnit, der gentages s. 357. På bogryggen mangler en vokal i forfatterens efternavn.

Det afgørende er selvfølgelig forfatteren Andreas Kappelers faglige forudsætninger. Han er schweizisk historiker og professor emeritus i østeuropæisk historie

Mette Skak er lektor ved Institut for Statskundskab, Aarhus Universitet. Hun har adskillige gange besøgt Rusland som led i sin forskning og er forfatter til utallige artikler og flere bøger. 
ved Universitetet i Wien, hvor han også er medlem af Videnskabernes Akademi. Han har adskillige æreshverv som ekspert $i$ de forhenværende sovjetiske nationale mindretal, herunder ukrainerne.

Det fine ved ham er, at han undgår det russo-centriske perspektiv, hvor ukrainerne ikke tillægges egne nationale aspirationer og handlekraft. Samtidig forbeholder Kappeler sig ret til at se med kritiske øjne på ukrainske nationale myter. Så sagligheden er i top men uden, at det ender i knastør tysk historieskrivning.

\section{Ud fra nutiden}

Ud over indledningen har bogen 18 kapitler begyndende med 'Ukraine og ukrainere: geografiske og etniske forhold' samt 'Kievriget og striden om dets arv' helt frem til det afsluttende kapitel 'Euro-Majdan, Ruslands indblanding og Ukraines destabilisering'. I indledningen går Kappeler befriende direkte til sagen ud fra følgende metode: 'Historie skrives ud fra nutiden'. Ukrainernes historie må skrives ud fra det faktum, at de siden 1991 har deres egen stat i medfør af Uafhængighedserklæringen af august 1991 samt opløsningen af Sovjetunionen. Men Uafhængighedserklæringens konkrete påstand om, at Ukraine har 'en tusindårig statslig tradition' er ren mytologi, understreger han.

Derved overses det lige så ubestridelige faktum, at Ukraine har været underlagt storfyrstendømmet Litauen, kongeriget Polen (fra 1569 Polen-Litauen), derpå det Russiske Imperium, Habsburgriget (Østrig) og i det 20. århundrede Polen og senest Sovjetunionen.
Hertil kommer fra 1700-tallet opdelingen i flere suverænitets- og kulturområder, hvad der er baggrunden for de mange stærke regionale identiteter i nutiden. I det omfang det lykkedes, var det Stalin, der ensrettede Ukraine i kølvandet på Anden Verdenskrig, tilføjer Kappeler. Som man forstår, er der langt fra Kappeler til den intellektuelle dovenskab, der afslører sig med klicheer som 'Ukraine har jo altid været spaltet i to'.

Kappeler slutter indledningen med at gøre status for Ukraine i det 21. århundrede:

"I 2014 gennemlevede Ukraine den værste krise siden Anden Verdenskrig. Ruslands intervention stillede spørgsmålstegn ved den uafhængige stats eksistens. Denne fare synes ved begyndelsen af september 2014, hvor jeg skriver disse ord, at være afværget, men Krim er besat, og krigen i Donbass er ikke afsluttet."

Det er situationen her i 2017. Bogens sidste kapitel giver en sober fremstilling af Majdan-revolutionen og efterspillet. Vedrørende den omstridte massakre på op mod hundrede ubevæbnede civile den 20. februar 2014 noterer han forlydender om, at der blandt Majdan-aktivisterne var snigskytter, der nedskød deres egne for at få krisen til at spidse til. Senere undersøgelser har ikke kunnet trænge til bunds i sagen, tilføjer han og vedgår sin tvivl. Dog vurderer han, at det var agents provocateurs fra Janukovitj' hold eller en plantet russisk 'nyhed'.

\section{Sammenhæng i historien}

Virkeligt berigende er Kappelers midterste kapitler, der skaber sammenhæng i Ukraines historie hen over hele 
det skrækkelige 20. århundrede. Ligesom i resten af Det Russiske Imperium pågik der en økonomisk og kulturel modernisering i tiden op til Første Verdenskrig, som faldt sammen med en national vækkelse - zarens politik var på det tidspunkt russificering, altså assimilation.

Ukraine ramtes af uroen omkring den første russiske revolution i 1905 mytteriet på panserkrydseren Potemkin omhandlede Sortehavsflåden og havnebyen Odessa. Nok så fatalt blev zarismens eneste fremsynede politiker, Pjotr Stolypin, skudt af en anarkist i Kiev-operaen i 1911. Men Ukraine nød ligesom Rusland godt af Stolypins landbrugsreformer takket være hans højre hånd, den danske landbrugssagkyndige C.A. Koefoed.

Donbass-området, der nu kendes som basen for Putins destabilisering af Ukraine, blomstrede op som sværindustriel bastion. Ukraines bidrag til zarismens BNP gennem eksport af hvede, jern, stål og kul var et afgørende moment i frygten for Ruslands voksende magt som årsag til udbruddet af Første Verdenskrig.

Verdenskrigen bragte Ukraine i klemme mellem det aggressive Tyskland, forbundsfællen Østrig og Ruslands giftige cocktail af militarisme og fravær af politiske reformer. Slagene på østfronten foregik ofte i Ukraine (Galicien). Det russiske revolutionsår 1917 åbnede for en stund for et selvstændigt Ukraine (1918-1921). Men magtkampen mellem de røde og de hvide betød borgerkrig og pogromer - 40.000 jøder blev dræbt, og i Kiev skiftede magten hænder ni gange på toethalvt år! Ukraine endte som Sovjetukraine, mens ukrainerne bittert kunne iagttage, hvordan Baltikum, Polen og Finland slog rod som fem af mellemkrigstidens uafhængige stater, skriver Kappeler.

Sovjetukraines historie blev den fuldbyrdede tragedie for landet og kulminerede under Stalin. Ganske vist indledtes 1920'erne med en mere fleksibel ukrainizatsia-politik, der skulle skabe lokale partitro kadrer. Følgelig anser Kappeler 1920'erne og 1950'erne for formative perioder for Ukraines nationsdannelse (ligesom senere Tjernobyl-katastrofen, Majdan-revolutionen og Putins chokterapi blev det).

Men så fulgte et folkemord på den ukrainske bondestand som led i 'likvideringen af kulakkerne som klasse' i hele Sovjetunionen - Stalins hævntogt mod den spontane 'udstykning' af storgodsejernes jord i årene 1917-20. Hertil kom den ukrainske sværindustris betydning som rygraden i Sovjetøkonomien samt, hvad bønderne angik, deres udbredte selvejermentalitet. Bolsjevikkerne brugte efterhånden smædeordet kurkul (ukrainsk for kulak, dvs. velstående bonde) om hvem som helst, der modsatte sig tvangskollektiviseringen af landbruget, skriver Kappeler.

200.000 såkaldte kulakgårde blev nedlagt, alt imens nogle ejere blev skudt, andre hundredtusinder deporteret til Sibirien.

\section{Holodomor}

Allerede i Lenins tid vakte de udbredte tvangsafleveringer af korn til staten for at generere et overskud til industrialiseringen stor modstand blandt bønderne. Derfor skulle de nu med djævlens vold 
og magt organiseres i kolkhoser, der effektivt inddrev deres korn og såsæd. Presset mod bønderne fik dem ofte til i desperation at slagte deres dyr og skabte en ond spiral af sult og yderligere overgreb mod bønderne. Resultatet var en forfærdelig hungersnød, der på ukrainsk hedder Holodomor dvs. det hungerskabte folkemord.

Kappeler taler om 4 mio.(!) omkomne hen over 1932 og 1933 alene i Ukraine, dvs. en afsindig høj andel af de samlede omkomne ved tvangskollektiviseringen. Kappeler skriver påfaldende forsigtigt om Stalins motiver til dette notoriske folkemord. Han konkluderer, at Stalin ville knække den ukrainske nationalisme, men afviser teorien om et planlagt folkemord med det søgte argument, at der ikke var tale om en fuldstændig udryddelse af ukrainerne.

Stanford-historikeren Norman M. Naimark anser Stalin for at være drevet af vrangforestillinger om ukrainske bønder og nationalister, der i ledtog med polske agenter ville løsrive Ukraine fra Sovjetunionen (Stalin's Genocides fra 2010).

Langtidseffekten af Holodomor, der var tabu i den sovjetiske historieforskning, blev den stik modsatte af hensigten. Under overfladen af indordning under Moskva og Stalin overvintrede den ukrainske nationalisme, hvad der fx gav problemer med forsvaret mod nazisterne i den første tid af Operation Barbarossa.

Men før den skulle Ukraine som resten af Sovjetunionen igennem den Store Terror sidst i 1930'erne, som var rettet mod eliten. Ud af 102 centralkomitémedlemmer i Ukraines kommu- nistparti var kun tre på fri fod i 1939, oplyser Kappeler. Blandt dem, der fyldte hullerne op, var Nikita Khrusjtjov, der var vokset op i Ukraine; hans forældre var russiske indvandrere. Som partichef havde han nu ansvaret for at russificere ukrainerne og proppe Sovjetpatriotisme og Stalinkult ned i halsen på dem. Det gjorde han med ordene:

"Kammerater! [...] nu lærer alle russisk, fordi den russiske arbejder har hejst revolutionens flag. Folkeslagene i hele verden lærer russisk for at studere leninismen og stalinismen og for at lære at ødelægge deres fjender. De borgerlige nationalister, de polske og tyske spioner forstår meget vel det russiske sprogs kraft og indflydelse, den russiske kultur, indflydelsen af Lenins og Stalins lære på det ukrainske folk. Derfor har de fjernet det russiske sprog fra skolerne." (s. 211).

\section{Molotov-Ribbentrop-pagten}

Denne kvalitative sovjetisering blev fulgt op af Molotov-Ribbentrop-pagtens kvantitative sovjetisering, der gjorde alle ukrainsk beboede territorier sovjetiske på nær Karpato-Ukraine. Før det var Galicien underlagt Polen, der i 1920'erne og 1930'erne ønskede en polonisering, hvad der både førte til dannelsen af Organisationen af Ukrainske Nationalister (OUN) i 1929 og en fascistisk drejning, der indbefattede den omstridte heltefigur for nutidens ukrainske højre, Stepan Bandera. Han blev ikke desto mindre arresteret af nazisterne og sendt i kz-lejr for så at blive løsladt i 1944 for at hjælpe mod Den Røde Hær. På Khrusjtjovs ordre blev Bandera dræbt af KGB i eksil i München i 1959. 
Anden Verdenskrig var modbydelig mod Ukraine, der igen blev slagmark; Kappeler citerer her rigskommissæren Erich Koch for, at det gjaldt om at knække fødselsraten, og Hitler for, at "ukrainerne er lige så dovne, uorganiserede og nihilistisk-asiatiske som storrusserne" (s. 226).

Mindst to mio. blev deporteret til Tyskland som ‘østarbejdere’, over 30.000 jøder blev skudt i Babyj Jar, 10.000 romaer blev dræbt osv. Kappeler opgør det samlede tab i menneskeliv mellem 1930 og 1944 til ca. 13 mio. Til sammenligning kostede selve Holocaust 6 mio. liv.

Fra 1943 begyndte OUN's kamp mod nazismen via den nationalistiske og antisovjetiske modstandshær UPA. I det tilbageerobrede Vestukraine fortsatte UPA's partisaner krigen mod Sovjetmagten helt ind i 1950'erne ligesom skovbrødrene i Baltikum. Deres modstander var Khrusjtjov, der i det hele taget havde medansvar for mange af Stalintidens uhyrligheder, men som i sin hemmelige tale på den 20. Partikongres afslørede, at Stalin overvejede kollektivt at straffe alle ukrainerne ligesom andre såkaldte kollaboratør-nationer med forvisning, skriver Kappeler.

Indtil Stalin døde, fortsatte den brutale og idiotiske sovjetisering. Derefter anlagde Khrusjtjov og senere sovjetiske ledere en mindre tonedøv kurs fx med overdragelsen af Krim til Ukraine i 1954.

Khrusjtjov blev afsat i 1964; meget bedre gik det ikke for Ukraines Petro Sjelest trods hans støtte til invasionen af Tjekkoslovakiet i 1968, fortæller Kappeler. Den daværende sovjetiske partichef Bresjnev tilhørte Ukraines Dnipropetrov-klan ligesom Volodimir Sjtjerbit- skij, der derfor blev Ukraines partichef. Han stod i 1972 for en udrensning i Ukraine, som Kappeler karakteriserer som 'det sovjetiske hemmelige politis mest omfattende aktion siden 1953'.

Ukraines åndelige liv forstenede ligesom i nabolandet Tjekkoslovakiet. Nu var devisen 'sammensmeltning af nationaliteterne til ét sovjetfolk' - læs: russificering. Man ville gøre ukrainerne til juniorpartnere for russerne i styringen af Sovjetunionen. Det gjorde Bresjnevs efterfølger Andropov ved at indsætte to ukrainske KGB-folk - Fedortjuk og Tjebrikov - i hovedkvarteret i Moskva som påskønnelse af det ukrainske KGB's helhjertede udrensning, konstaterer Kappeler tørt. Tjebrikov avancerede til KGB-chef under Gorbatjov.

\section{Den sovjetiske ørkenvandring}

Summa summarum en spændende kulegravning af Ukraines lange sovjetiske ørkenvandring, som andre fremstillinger højst giver et par stikord til.

Gorbatjov bibeholdt jernnæven Sjtjerbitskij, så først med Tjernobyl-katastrofen i 1986 vågnede Ukraine op, skriver Kappeler. Det førte frem til uafhængighedsbevægelsen Rukh i 1989 og til, at hele 90 pct. af befolkningen - ukrainere, russere osv. - 1. december 1991 stemte for et selvstændigt Ukraine. Få dage efter kom topmødet mellem Rusland, Ukraine og Hviderusland, der oprettede SNG til erstatning for Sovjetunionen.

Kappelers gennemgang af Ukraines omtumlede postsovjetiske historie er lige så livlig. Læsere med blot den mindste interesse for Ukraine bør snarest kaste sig over bogen! 